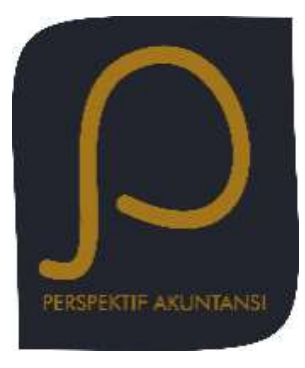

Perspektif Akuntansi

Volume 2 Nomor 1 (Februari 2019), hal. 53-70

ISSN: 2623-0194(Print), 2623-0186(Online) Copyright(C) The Authors(s). All Rights Reserved

Fakultas Ekonomika dan Bisnis,

Universitas Kristen Satya Wacana

DOI: https://doi.org/10.24246/persi.v2i1.p53-70

http://ejournal.uksw.edu/persi

\title{
Sikap Etis Mahasiswa: Pengaruh Kecerdasan Parsial dan Simultan
}

\author{
Tabeta Christy \\ Fakultas Ekonomika dan Bisnis Universitas Kristen Satya Wacana \\ Like Soegiono \\ Fakultas Ekonomika dan Bisnis Universitas Kristen Satya Wacana \\ Aprina Nugrahesthy Sulistya Hapsari ${ }^{1}$ \\ Fakultas Ekonomika dan Bisnis Universitas Kristen Satya Wacana
}

Received Abstract. This study aims to provide empirical evidence about the

11/01/2019 influence of intellectual intelligence, emotional intelligence, and spiritual intelligence toward ethical attitudes of university accounting Accepted students on ethic profession of accountant. It is based on the 24/01/2019 phenomenon of many ethical scandals, especially related to the accounting profession. Purposive sampling technique is chosen with criteria respondents have done professional ethic subject. Data was gathered by questionnaires. Data analysis to test hypothesis is done with multiple linear regression analysis. This research results shows that emotional intelligence, intellectual intelligence, and spiritual intelligence simultaneously had significantly effect on ethical attitudes of university accounting students. However partially, only IQ has significantly positive effects on ethical attitudes of university accounting students on ethic profession of accountant. This research contributes to adding insight in the field of behavioral accounting and psychology which is shown by ethical attitude in the accountant profession seen from the side of emotional intelligence, intellectual intelligence and spiritual intelligence.

Keywords: emotional intelligence, intellectual intelligence, spiritual intelligence, ethical attitudes

Abstrak. Penelitian ini bertujuan untuk memberikan bukti secara empiris mengenai pengaruh kecerdasan emosional, kecerdasan

1 esthy@staff.uksw.edu 


\begin{abstract}
intelektual, dan kecerdasan spiritual terhadap sikap etis mahasiswa akuntansi atas etika profesi akuntan. Pengambilan sampel menggunakan metoda purposive sampling dengan kriteria responden telah mengambil mata kuliah etika profesi. Data dikumpulkan dengan menggunakan kuesioner. Alat pengujian hipotesis yang digunakan adalah analisis regresi linear berganda. Hasil pada penelitian ini membuktikan bahwa kecerdasan emosional, kecerdasan intelektual, dan kecerdasan spiritual secara simultan berpengaruh positif signifikan terhadap sikap etis mahasiswa akuntansi atas etika profesi akuntan. Namun secara parsial, hanya kecerdasan intelektual yang berpengaruh positif signifikan terhadap sikap etis mahasiswa akuntansi atas etika profesi akuntan. Penelitian ini memberikan kontribusi untuk menambah wawasan di bidang akuntansi perilaku dan psikologi yang ditunjukkan oleh sikap etis dalam profesi akuntan dilihat dari sisi kecerdasan emosional, kecerdasan intelektual dan kecerdasan spiritual.
\end{abstract}

Kata kunci: Kecerdasan intelektual, kecerdasan emosional, kecerdasan spiritual, sikap etis

\title{
Pendahuluan
}

Skandal etis merupakan isu yang selalu menarik untuk diteliti terkait aspek perilaku profesional dalam organisasi. Individu maupun kelompok terkadang kurang sadar dalam menjunjung tinggi dan mengedepankan sikap etis dalam bekerja yang berakibat pada terciptanya skandal etis yang berakibat pada kerugian bagi organisasi maupun pemangku kepentingan di luar organisasi tersebut (Agustini \& Herawati, 2013). Fenomena skandal etis yang sempat menjadi perhatian khusus di Indonesia antara lain adalah: (a) kasus korupsi eKTP oleh mantan Dirjen Dukcapil dan mantan Direktur Pengelola Informasi Administrasi Kependudukan Ditjen Dukcapil (Suprayogi, 2017); (b) kasus suap Ditjen Pajak oleh PT Eka Prima Ekspor (EKP) Indonesia (Santoso, 2017); (c) pemberian sanksi kepada KAP Purwantono karena gagal untuk mengaudit laporan keuangan kliennya (Malik, 2017). Munculnya kasus skandal etis tersebut disebabkan oleh etika individu tidak sesuai dengan kode etik profesi yang telah ditetapkan.

Etika di dunia pendidikan belakangan ini juga menjadi fenomena yang menarik untuk kemudian dikaji, terutama terkait perilaku etis mahasiswa. Fenomena ini diawali dengan adanya penurunan etika sosial yang diciderai oleh hilangnya kesadaran dalam berkomunikasi antara mahasiswa dengan dosen (Dzulkifli, 2016). Berikutnya disusul dengan adanya fenomena kecurangan akademik juga sering terjadi di institusi pendidikan, seperti yang dikemukakan oleh Purnamasari (2013) yaitu sebanyak 53,6 persen mahasiswa pernah melakukan kecurangan akademik. Bentuk kecurangan akademik yang dilakukan pun beragam, seperti menyontek pekerjaan teman saat ujian, membuka buku saat 
ujian, menyalin tugas teman, dan copy paste dari internet (Nursalam, Bani, \& Munirah, 2013). Nilai-nilai yang dimiliki mahasiswa, seperti kejujuran, keadilan, tanggung jawab dan penghargaan terhadap diri sendiri yang telah menyatu akan terpicu ketika mahasiswa menghadapi kondisi yang membutuhkan pertimbangan etis terkait moral.

Etika individu bisa dijumpai baik dari kalangan profesional maupun mahasiswa sebagai bagian dari lingkungan akademik. Sikap etis khususnya pada diri mahasiswa merupakan hal yang menarik diteliti karena akan mempengaruhi perilaku etis dan profesional ketika bekerja. Mahasiswa sebagai intelektual muda dalam menjalankan aktivitas studinya dipengaruhi baik oleh kecerdasan emosional, kecerdasan intelektual, dan kecerdasan spiritual yang akan membentuk sikap etis dalam pengambilan keputusan.

Penelitian Lawson (2004) membuktikan adanya hubungan yang kuat antara kecenderungan melakukan tindakan etis dalam bangku pendidikan dengan perilaku etis mereka di dunia kerja. Penelitian ini mengangkat isu mengenai etika sebagai sebuah hal penting di bidang akuntansi yang diajarkan pada perguruan tinggi. Lingkungan pendidikan memiliki pengaruh dalam pembentukan karakter mahasiswa sehingga menjadi seorang yang dapat berperilaku etis. Hal ini sesuai dengan pendapat Hastuti (2012) yang menyatakan bahwa perguruan tinggi adalah tempat menghasilkan sumber daya manusia yang mempunyai keahlian sesuai dengan bidangnya dan juga dapat bertindak sesuai dengan kode etik profesinya.

Pembekalan mengenai etika profesi di perguruan tinggi dapat menjadi sebuah cara dalam membentuk karakter etis individu. Di sisi lain hasil penelitian O'Clock \& Okleshen (1993) menyatakan bahwa mahasiswa akuntansi memiliki tingkat kesadaran yang lebih rendah daripada mahasiswa non akuntansi. Hal ini menjadi critical review bagi perguruan tinggi, khususnya program studi akuntansi. Saat ini banyak perguruan tinggi berupaya untuk mengintegrasikan materi terkait etika ke dalam kurikulum pembelajaran, sehingga diharapkan mahasiswa dapat memiliki kecerdasan emosional, kecerdasan intelektual, dan kecerdasan spiritual sehubungan dengan pengajaran etika profesi di bangku perkuliahan.

Penelitian terdahulu mengenai sikap etis pernah dilakukan oleh Ika (2011) menyatakan bahwa kecerdasan emosional tidak berpengaruh atas sikap etis mahasiswa namun kecerdasan spiritual berpengaruh signifikan dan dominan terhadap sikap etis. Hasil tersebut berbeda dengan penelitian yang dilakukan oleh Tikollah, Triyuwono, \& Ludigdo (2006) yang mengungkapkan kecerdasan intelektual berpengaruh signifikan dan dominan terhadap sikap etis 
mahasiswa, sedangkan kecerdasan emosional maupun kecerdasan spiritual tidak berpengaruh terhadap sikap etis mahasiswa.

Ketidakkonsistenan hasil penelitian inilah yang mendorong penelitian ini dilakukan, yaitu untuk menguji kembali pengaruh kecerdasan emosional, kecerdasan intelektual, dan kecerdasan spiritual yang ditujukan pada mahasiswa Program Studi Akuntansi Fakultas Ekonomika dan Bisnis, Universitas Kristen Satya Wacana (FEB UKSW). Salah satu profil lulusan yang diharapkan oleh FEB UKSW adalah akuntan profesional yang memiliki integritas dalam profesinya. Dalam rangka membentuk integritas yang ada pada lulusan, maka sejak awal mahasiswa perlu memiliki sikap etis sebelum mereka terjun ke dunia profesional nantinya.

Tujuan dari penelitian ini adalah untuk memberikan bukti secara empiris mengenai pengaruh kecerdasan emosional, kecerdasan intelektual, dan kecerdasan spiritual terhadap sikap etis mahasiswa akuntansi di FEB UKSW. Hasil dari penelitian ini diharapkan dapat memberikan manfaat bagi Program Studi Akuntansi untuk dapat membekali para mahasiswanya di dalam proses pembelajaran sehingga dapat menghasilkan tenaga kerja yang tidak hanya berkemampuan akademik yang baik namun dapat bertindak sesuai dengan etika profesinya. Penelitian ini juga diharapkan dapat memberikan manfaat bagi mahasiswa untuk mengembangkan kecerdasannya tanpa mengabaikan sikap etisnya. Selain itu, manfaat akademik pada penelitian ini adalah memberikan kontribusi bagi pengembangan ilmu pengetahuan pada bidang akuntansi keperilakuan serta sebagai referensi bagi berbagai pihak yang akan mengadakan kajian mengenai pengaruh kecerdasan intelektual, kecerdasan emosional, dan kecerdasan spiritual terhadap sikap etis mahasiswa.

\section{Telaah Pustaka}

\section{Sikap Etis atas Etika Profesi Akuntan}

Menurut Soetarno (1994) sikap adalah pandangan atau perasaan yang disertai kecenderungan untuk bertindak terhadap objek tertentu. Hal ini sejalan dengan pendapat Thurstone (1928) yang menyatakan bahwa sikap adalah bentuk evaluasi atau reaksi perasaan terhadap suatu objek, yang dapat berupa mendukung atau memihak maupun tidak mendukung atau tidak memihak. Sikap bukanlah perilaku namun sikap merupakan kecenderungan untuk berperilaku menggunakan metode tertentu (Rakhmat, 2005).

Boynton, Johnson, \& Kell (2014) mendefinisikan bahwa etika merupakan suatu pertanyaan mengenai bagaimana perilaku individu terhadap sesamanya. Etika merupakan kajian yang membahas mengenai tindakan manusia tentang apa yang baik dan buruk untuk menjalankan hubungan antar sesama manusia, 
alam, dan Tuhan. Etika bukan hanya mengenai bagaimana mengerti tentang konsep dan kajiannya, tetapi lebih dari itu bagaimana manusia dapat bertindak dengan baik dan dapat menemukan makna untuk mencapai kedewasaan emosi dan mencapai kesadaran diri lebih baik lagi (Agoes \& Ardana, 2009). Menurut Griffin \& Ebert dalam Maryani \& Ludigdo (2001), sikap etis adalah sikap yang sesuai sengan norma-norma sosial yang diterima secara umum yang berkaitan dengan tindakan-tindakan yang bermanfaat dan yang tidak membahayakan.

Etika sebagai salah satu unsur utama dari profesi menjadi landasan bagi akuntan dalam menjalankan kegiatan profesional. Akuntan memiliki tanggung jawab untuk bertindak sesuai dengan kepentingan publik. Dalam Kode Etik Akuntan Profesional (Ikatan Akuntan Indonesia, 2016) ditetapkan bahwa seorang akuntan dalam melakukan pekerjaan profesional harus memiliki kelima prinsip dasar etika yang telah ditetapkan, yaitu:

(a) Integritas, yaitu bersikap lugas dan jujur dalam semua hubungan profesional dan bisnis; (b) Objektivitas, yaitu tidak membiarkan bias, benturan kepentingan, atau pengaruh yang tidak semestinya dari pihak lain, yang dapat mengesampingkan pertimbangan profesional atau bisnis; (c) Kompetensi dan kehati-hatian profesional, yaitu menjaga pengetahuan dan keahlian profesional pada tingkat yang dibutuhkan untuk memastikan bahwa klien atau pemberi kerja akan menerima jasa profesional yang kompeten berdasarkan perkembangan praktik, peraturan, dan teknik mutakhir, serta bertindak sungguh-sungguh dan sesuai dengan teknik dan standar profesional yang berlaku; (d) Kerahasiaan, yaitu menghormati kerahasiaan informasi yang diperoleh dari hasil hubungan profesional dan bisnis dengan tidak mengungkapkan informasi tersebut kepada pihak ketiga tanpa ada kewenangan yang jelas dan memadai, kecuali terdapat suatu hak atau kewajiban hukum atau profesional untuk mengungkapkannya, serta tidak menggunakan informasi tersebut untuk keuntungan pribadi Akuntan Profesional atau pihak ketiga; (e) Perilaku Profesional, yaitu mematuhi hukum dan peraturan yang berlaku dan menghindari perilaku apapun yang mengurangi kepercayaan kepada profesi Akuntan Profesional.

\section{Kecerdasan Emosional}

Goleman (2004) mendefinisikan kecerdasan emosional merupakan kecerdasan untuk memotivasi diri sendiri, mengendalikan keinginan hati, bertahan dalam menghadapi masalah, dan menjaga emosi agar tidak mengganggu kemampuan berpikir. Dengan kata lain, kecerdasan emosional merupakan kemampuan manusia untuk mengendalikan perasaan dalam menghadapi masalah hidupnya. Menurut Goleman (2004) kecerdasan emosional terbagi menjadi lima komponen utama, yaitu: 1) Kesadaran Diri (Self Awareness); 2) Pengaturan 
Diri (Self Management); 3) Motivasi (Self Motivation); 4) Empati (Empathy/Social awareness); dan 5) Ketrampilan Sosial (Relationship Management).

\section{Kecerdasan Intelektual}

Moustafa \& Miller (2003) mengemukakan bahwa kecerdasan intelektual adalah kemampuan kognitif yang terdiri dari kemampuan verbal, kemampuan matematika, dan kemampuan ruang. Hal ini berarti bahwa kecerdasan intelektual merupakan kemampuan manusia dalam mengelola akal dan pikiran yang dimiliki. Sementara itu dimensi kecerdasan yang membentuk kecerdasan intelektual yaitu meliputi tujuh hal, yaitu:

1) Kecerdasan numerik adalah kemampuan dalam menangkap serta mengeloh angka dan data; 2) Pemahaman verbal adalah kemampuan yang berkaitan dengan kemampuan menulis, membaca, dan berbicara; 3) Kecepatan persepsi adalah kecerdasan untuk mengidentifikasi kemiripan maupun perbedaan visual dengan cepat dan akurat; 4) Penalaran induktif adalah kecerdasan dalam melakukan identifikasi urutan logis dalam sebuah masalah dan menemukan solusi masalah itu; 5) Penalaran deduktif adalah kemampuan untuk menggunakan logika dan menilai implikasi dari sebuah argumen; 6) Visualisasi spasial adalah kemampuan membayangkan bagaimana sebuah objek akan terlihat bila posisi dalam ruangan diubah; dan 7) Ingatan yang baik merupakan kemampuan dalam menahan dan mengenang kembali pengalaman masa lalu.

\section{Kecerdasan Spiritual}

Kecerdasan spiritual merupakan kemampuan dalam memecahkan persoalan nilai dan makna, yaitu kecerdasan untuk menempatkan perilaku dan hidup dalam konteks makna yang lebih luas dan kaya (Zohar \& Marshall, 2001). Kecerdasan emosional, intelektual, dan spiritual adalah satu rangkaian konsep kecerdasan yang tidak bisa dipisahkan dengan kecerdasan spiritual sebagai dasar dari tiga kecerdasan ini (Agoes \& Ardana, 2009). Menurut Zohar \& Marshall (2001) terdapat sepuluh kriteria untuk mengukur kecerdasan spiritual seseorang, yaitu:

a) Kesadaran diri; b) Spontanitas, termotivasi secara internal; c) Melihat kehidupan dari visi dan berdasarkan nilai-nilai fundamental; d) Holistik, melihat sistem dan universalitas; e) Kasih sayang (rasa berkomunitas, rasa mengikuti aliran kehidupan); f) Menghargai keragaman; g) Mandiri, teguh melawan mayoritas; h) Mempertanyakan secara mendasar; i) Menata kembali dalam gambaran besar; j) Teguh dalam kesulitan. 


\section{Pengembangan Hipotesis}

\section{Pengaruh Kecerdasan Emosional Terhadap Sikap Etis Atas Etika Profesi Akuntan}

Menurut Melandy \& Aziza (2006) kecerdasan emosional mempunyai peran lebih dari 80 persen dalam mencapai kesuksesan, baik dalam kehidupan pribadi maupun kehidupan profesional. Setiap keputusan yang diambil manusia melibatkan emosi yang ada dalam diri masing-masing individu. Apabila seseorang mempunyai kecerdasan emosional yang tinggi, maka keputusan yang dibuatnya pun akan tepat dan tidak merugikan lingkungan sekitar. Oleh karena itu, pengendalian emosi menjadi hal yang perlu diperhatikan.

Emosi juga berpengaruh pada keputusan yang diambil oleh mahasiswa akuntansi. Pada saat di kemudian hari mahasiswa dihadapkan pada lingkungan pekerjaan maupun kode etik profesi, emosi mahasiswa pun akan terlibat dalam pengambilan keputusan. Keputusan yang diambil mahasiswa tergantung pada fokus mahasiswa sendiri apakah kepentingan pribadi atau kode etik profesi. Apabila mahasiswa akuntansi memiliki kecerdasan emosional yang tinggi, maka mahasiswa akan memiliki empati dan pengendalian diri yang tinggi pula. Pengendalian diri berkaitan dengan kemampuan memahami diri sendiri, sedangkan empati berkaitan dengan kemampuan memahami orang lain sehingga tidak menimbulkan tindakan yang merugikan orang lain (Patton, 2002). Kedua hal ini akan membuat mahasiswa akuntansi memiliki sikap yang sesuai dengan kode etik profesi yang berlaku dan tidak hanya mengutamakan kepentingan pribadinya.

Penelitian sebelumnya mengenai pengaruh kecerdasan emosional terhadap sikap etis mahasiwa akuntansi telah dilakukan oleh Wardana \& Mimba (2016). Hasil dari penelitian tersebut adalah bahwa kecerdasan emosional berpengaruh positif terhadap sikap etis mahasiswa akuntansi, sehingga hipotesis pertama dalam penelitian ini adalah:

$\mathbf{H}_{\mathbf{1}}$ : Kecerdasan emosional berpengaruh positif terhadap sikap etis atas etika profesi akuntan.

\section{Pengaruh Kecerdasan Intelektual Terhadap Sikap Etis Mahasiswa Akuntansi}

Kecerdasan intelektual merupakan kecerdasan yang dimiliki oleh manusia untuk menganalisis suatu permasalahan dan menghasilkan strategi untuk penyelesaian masalah tersebut (Zohar \& Marshall, 2001). Kecerdasan ini tidak melibatkan perasaan (emosi) namun berdasarkan pengetahuan dan logika yang tepat. 
Dalam bukunya, Purwanto (2017) mendefinisikan kecerdasan intelektual sebagai kesanggupan untuk beradaptasi kepada kebutuhan baru dengan menggunakan alat-alat berpikir yang sesuai dengan tujuan. Hal ini dapat diartikan apabila mahasiswa akuntansi memiliki kecerdasan intelektual yang tinggi maka mereka akan menggunakan logikanya untuk berpikir apa yang akan dilakukan dan bagaimana dampak dari tindakan tersebut. Apabila mahasiswa memiliki kecerdasan intelektual yang tinggi, maka mahasiswa dapat menerapkan pengetahuan mengenai etika yang sudah diberikan pada masa perkuliahan. Hal ini membuat mahasiswa dapat bertindak sesuai dengan kode etik profesi.

Penelitian tentang kecerdasan intelektual yang dilakukan oleh Tikollah et al. (2006) menyatakan bahwa pandangan kelompok yang menekankan kecerdasan intelektual sebagai kemampuan adaptasi, serta orang yang inteligen (cerdas) akan mempunyai kemampuan untuk mengorganisasi pola-pola tingkah lakunya sehingga dapat bertindak lebih efektif dan lebih tepat. Hal ini dapat diartikan bahwa semakin tinggi kecerdasan intelektual individu maka akan semakin terdorong untuk bersikap etis sesuai dengan etika profesi.

Penelitian sebelumnya tentang pengaruh kecerdasan intelektual terhadap sikap etis mahasiwa akuntansi telah dilakukan oleh Wardana \& Mimba (2016). Hasil penelitian tersebut menunjukkan bahwa kecerdasan intelektual berpengaruh positif signifikan terhadap sikap etis mahasiswa akuntansi, sehingga hipotesis kedua pada penelitian ini adalah:

$\mathbf{H}_{2}$ : Kecerdasan intelektual berpengaruh positif terhadap sikap etis mahasiswa akuntansi atas etika profesi akuntan.

Pengaruh Kecerdasan Spiritual Terhadap Sikap Etis Mahasiswa Akuntansi Atas Etika Profesi Akuntan

Individu yang memiliki kecerdasan spiritual tinggi maka akan memiliki kesadaran yang tinggi, mempunyai kemudahan untuk melawan rasa untuk melakukan tindakan yang menentang kebenaran, dan mampu untuk menjalankan perintah Tuhan. Bhagavad Gita pada ayat sloka 2.66 mengungkapkan kecerdasan spiritual sebagai berikut:

Orang yang tidak mempunyai hubungan dengan Yang Maha Kuasa tidak mungkin memiliki kecerdasan rohani maupun pikiran yang mantap. Tanpa kecerdasan rohani dan pikiran yang mantap tidak mungkin ada kedamaian.

Tanpa kedamaian, mana mungkin ada kebahagiaan?

Hal ini dapat diartikan bahwa apabila mahasiswa akuntansi memiliki kecerdasan spiritual yang tinggi maka mereka akan mencari kedamaian, 
sehingga mereka akan mengikuti apa yang dikehendaki oleh Tuhan dan memiliki sikap etis agar mereka mendapatkan kedamaian. Dengan demikian, kecerdasan spiritual memiliki pengaruh positif terhadap sikap etis mahasiswa karena dengan kemampuan untuk merefleksikan nilai dan aspek-aspek kehidupan yang baik maka mahasiswa akuntansi akan memiliki sikap etis pada etika profesi.

Penelitian sebelumnya mengenai pengaruh kecerdasan spiritual terhadap sikap etis mahasiwa akuntansi telah dilakukan oleh Ika (2011); Wardana \& Mimba (2016). Hasil dari kedua penelitian tersebut adalah bahwa kecerdasan spiritual berpengaruh positif signifikan terhadap sikap etis mahasiswa akuntansi, sehingga hipotesis ketiga pada penelitian ini adalah:

$\mathbf{H}_{3}$ : Kecerdasan spiritual berpengaruh positif terhadap sikap etis mahasiswa akuntansi atas etika profesi akuntan.

Pengaruh Kecerdasan Emosional, Kecerdasan Intelektual, Kecerdasan Spiritual Terhadap Sikap Etis Mahasiswa Akuntansi Atas Etika Profesi

Bagi orang yang mempunyai kecerdasan emosional yang tinggi, mereka lebih mempunyai keseimbangan dalam mengelola emosi mereka, baik dalam bersikap maupun dalam berhubungan. Meskipun demikian menurut Agoes \& Ardana (2009) dalam kajian dan implementasi etika melibatkan ketiga kecerdasan secara terpadu, yaitu kecerdasan intelektual, kecerdasan emosional, dan kecerdasan spiritual. Oleh karena itu, kecerdasan intelektual dan kecerdasan spiritual juga harus dimiliki secara bersama-sama agar sikap etis dapat difungsikan lebih efektif.

Penelitian sebelumnya mengenai pengaruh kecerdasan emosional, kecerdasan intelektual, dan kecerdasan spiritual terhadap sikap etis mahasiwa akuntansi telah dilakukan oleh Tikollah et al. (2006); Wardana \& Mimba (2016). Hasil dari kedua penelitian tersebut menunjukkan bahwa kecerdasan emosional, kecerdasan intelektual, dan kecerdasan spiritual secara simultan berpengaruh positif signifikan terhadap sikap etis mahasiswa akuntansi. Berdasarkan penelitian tersebut, maka hipotesis keempat pada penelitian ini adalah:

$\mathbf{H}_{4}$ : Kecerdasan emosional, kecerdasan intelektual, dan kecerdasan spiritual berpengaruh positif terhadap sikap etis mahasiswa akuntansi atas etika profesi akuntan. 


\section{Model Penelitian}

Berdasarkan rumusan hipotesis di atas, maka model penelitian ini dapat dilihat pada Gambar 1.

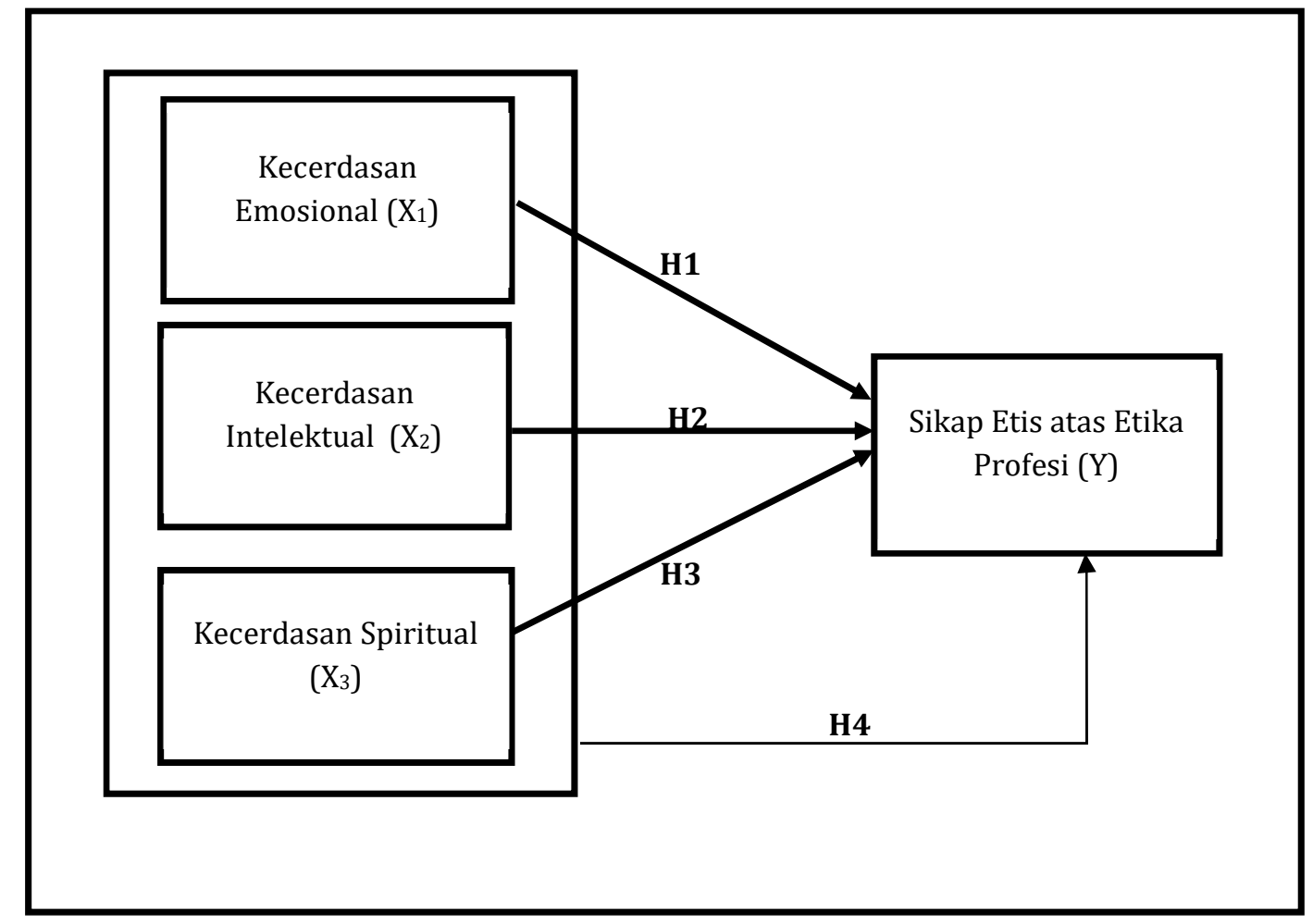

Gambar 1. Model Penelitian

\section{Metoda}

\section{Jenis Penelitian, Populasi Dan Sampel}

Populasi penelitian ini adalah mahasiswa Program Studi Akuntansi FEB UKSW. Adapun sampel penelitian diperoleh dengan cara purposive sampling, yaitu dengan kriteria mahasiswa angkatan aktif dan sudah mengambil mata kuliah etika profesi. Mata kuliah etika profesi mengajarkan mahasiswa akuntansi mengenai prinsip-prinsip etis yang harus mahasiswa lakukan sesuai dengan kode etik profesi akuntan profesional maupun akuntan publik. Oleh karena itu, mahasiswa yang sudah mengambil mata kuliah etika profesi dianggap telah memiliki pengetahuan mengenai etika sehingga mempunyai dasar dalam bersikap.

\section{Jenis, Sumber dan Teknik Pengumpulan Data}

Penelitian ini menggunakan data primer yang diperoleh langsung dari responden dengan bantuan kuesioner (lima skala likert). Data yang 
dikumpulkan pada penelitian ini adalah data primer. Data tersebut diperoleh dengan cara mengedarkan kuesioner kepada 180 responden, disesuaikan dengan jumlah mahasiswa aktif yang telah mengambil mata kuliah Etika Profesi. Dari 180 kuesioner yang dibagikan kepada responden, hanya 150 kuesioner yang terkumpul. Sejumlan 30 kuesioner yang tidak diolah dalam penelitian ini disebabkan kuesioner tersebut tidak terisi lengkap.

\section{Definisi Operasional}

Berikut ini adalah Tabel 1 tentang definisi operasional variabel dalam penelitian ini:

\section{Tabel 1. Definisi Operasional}

\begin{tabular}{|c|c|c|c|}
\hline No. & Variabel & Definisi Operasional & Indikator Empiris \\
\hline 1. & Sikap Etis (Y) & $\begin{array}{l}\text { Menurut Griffin dan Ebert } \\
\text { (dalam Maryani dan Ludigdo } \\
(2001) \text { ), sikap etis adalah } \\
\text { sikap yang sesuai sengan } \\
\text { norma-norma sosial yang } \\
\text { diterima secara umum yang } \\
\text { berkaitan dengan tindakan - } \\
\text { tindakan yang bermanfaat } \\
\text { dan yang tidak } \\
\text { membahayakan. }\end{array}$ & $\begin{array}{l}\text { Integritas } \\
\text { Objektivitas } \\
\text { Kompetensi dan kehati- } \\
\text { hatian profesional } \\
\text { Kerahasiaan } \\
\text { Perilaku Profesional }\end{array}$ \\
\hline 2. & $\begin{array}{l}\text { Kecerdasan } \\
\text { Emosional } \\
\text { (X1) }\end{array}$ & $\begin{array}{l}\text { Goleman (2004) } \\
\text { mendefinisikan kecerdasan } \\
\text { emosional merupakan } \\
\text { kecerdasan untuk } \\
\text { memotivasi diri sendiri, } \\
\text { mengendalikan keinginan } \\
\text { hati, bertahan dalam } \\
\text { menghadapi masalah, dan } \\
\text { menjaga emosi agar tidak } \\
\text { mengganggu kemampuan } \\
\text { berpikir. }\end{array}$ & $\begin{array}{l}\text { Kesadaran Diri (Self } \\
\text { Awareness) } \\
\text { Pengaturan Diri (Self } \\
\text { Management) } \\
\text { Motivasi (Self Motivation) } \\
\text { Empati (Empathy/Social } \\
\text { awareness) } \\
\text { Ketrampilan Sosial } \\
\text { (Relationship Management) }\end{array}$ \\
\hline 3. & $\begin{array}{l}\text { Kecerdasan } \\
\text { Intelektual } \\
\text { (X2) }\end{array}$ & $\begin{array}{l}\text { Moustafa dan Miller (2003) } \\
\text { mengemukakan bahwa } \\
\text { kecerdasan intelektual } \\
\text { adalah kemampuan kognitif } \\
\text { yang terdiri dari } \\
\text { kemampuan verbal, } \\
\text { kemampuan matematika, } \\
\text { dan kemampuan ruang. }\end{array}$ & $\begin{array}{l}\text { Kecerdasan numerik } \\
\text { Pemahaman verbal } \\
\text { Kecepatan persepsi } \\
\text { Penalaran induktif } \\
\text { Penalaran deduktif } \\
\text { Visualisasi spasial } \\
\text { Ingatan yang baik }\end{array}$ \\
\hline 4. & $\begin{array}{l}\text { Kecerdasan } \\
\text { Spiritual (X3) }\end{array}$ & $\begin{array}{l}\text { Kecerdasan Spiritual adalah } \\
\text { kemampuan dalam } \\
\text { memecahkan persoalan } \\
\text { makna dan nilai, yaitu } \\
\text { kecerdasan untuk } \\
\text { menempatkan perilaku dan } \\
\text { hidup dalam konteks makna }\end{array}$ & $\begin{array}{l}\text { Kesadaran Diri } \\
\text { Spontanitas, termotivasi } \\
\text { secara internal } \\
\text { Melihat kehidupan dari visi } \\
\text { dan berdasrkan nilai-nilai } \\
\text { fundamental }\end{array}$ \\
\hline
\end{tabular}




\begin{tabular}{|c|c|c|c|}
\hline No. & Variabel & Definisi Operasional & Indikator Empiris \\
\hline & & $\begin{array}{l}\text { yang lebih luas dan kaya } \\
\text { (Zohar \& Marshall, 2001). }\end{array}$ & $\begin{array}{l}\text { Holistik, melihat sistem dan } \\
\text { universalitas } \\
\text { Kasih sayang (rasa } \\
\text { berkomunitas, rasa } \\
\text { mengikuti aliran kehidupan) } \\
\text { Menghargai keragaman } \\
\text { Mandiri, teguh melawan } \\
\text { mayoritas } \\
\text { Mempertanyakan secara } \\
\text { mendasar } \\
\text { Menata kembali dalam } \\
\text { gambaran besar } \\
\text { Teguh dalam kesulitan }\end{array}$ \\
\hline
\end{tabular}

\section{Teknik Analisis Data}

Teknik analisis data yang digunakan untuk menguuji instrumen pada penelitian ini adalah uji validitas dan uji reliabilitas. Uji validitas pada penelitian ini menggunakan uji corrected item total correlation. Jika $r$ hitung $>r$ tabel dan bernilai positif maka butir pernyataan atau indikator tersebut dinyatakan valid. Namun, jika $r$ hitung < r tabel maka variabel tersebut tidak valid. Uji reliabilitas setiap variabel pada penelitian ini diukur dengan menggunakan cronbach's alpha. Reliabilitas suatu variabel dikatakan baik jika memiliki nilai Alpha Cronbach's > 0,6 (Ghozali, 2013).

Uji asumsi klasik yang dilakukan pada penelitian ini adalah uji normalitas, uji heterokedastisitas, dan uji multikolinearitas. Dalam penelitian ini, uji normalitas setiap variabel diukur dengan menggunakan kolmogorov-smirnov. Jika angka Sig. lebih besar atau sama dengan 0,05 maka data tersebut berdistribusi normal namun apabila kurang dari 0,05 maka data tersebut tidak berdistribusi normal. Uji heteroskedasitas pada penelitian ini menggunakan uji glejser dengan melakukan pengujian regresi terhadap variabel bebas dan variabel terikat menjadi absolut erornya. Apabila nilai Sig $>0,05$ maka tidak terjadi gejala heteroskedastisitas. Uji multikolinearitas pada penelitian ini dilakukan dengan melihat nilai inflation factor (VIF) pada model regresi. Apabila tolerance value $<0,10$ atau VIF $>10$ maka terjadi multikolinearitas. Namun, jika tolerance value $>0,10$ atau VIF $<10$ maka tidak terjadi multikolinearitas.

Uji hipotesis dilakukan dengan menggunakan analisis regresi linier berganda dengan uji t untuk melihat hubungan antara variabel bebas dan variabel terikat secara simultan dan uji $\mathrm{F}$ untuk melihat hubungan antara variabel bebas dan terikat secara parsial. Pada pengujian ini menggunakan tingkat signifikansi sebesar $10 \%$ atau 0,1. Jika nilai Sig. < $\alpha$, maka Ha diterima (Ghozali, 2013). 
Model regresi yang digunakan dalam penelitian ini menggunakan rumus sebagai berikut:

$Y=a+\beta_{1} X_{1}+\beta_{2} X_{2}+\beta_{3} X_{3}+e$

Keterangan:

$\mathrm{Y}=$ = Sikap Etis Mahasiwa Akuntansi UKSW

a $\quad=$ Konstanta

$B=$ Koefisien masing - masing variabel $X_{1}, X_{2}$, danX $X_{3}$

$\mathrm{X}_{1} \quad=$ Kecerdasan Emosional

$\mathrm{X}_{2} \quad=$ Kecerdasan Intelektual

$\mathrm{X}_{3}=$ Kecerdasan Spiritual

e $\quad=$ Error term

\section{Hasil dan Pembahasan}

\section{Hasil}

\section{Profil Responden}

Jenis kelamin responden dalam penelitian ini terdiri dari 41 persen laki-laki dan 59 persen perempuan. Mahasiswa yang telah mengisi kuesioner penelitian ini adalah yang telah mengambil mata kuliah Etika Profesi, yang seluruhnya adalah mahasiswa angkatan 2014.

\section{Analisis Statistik Deskriptif}

Hasil statistik deskriptif pada Tabel 2 menunjukkan nilai minimum variabel sikap etis sebesar 12 yang berarti responden dominan menjawab dengan poin TS (tidak setuju) atau STS (sangat tidak setuju). Nilai maksimum sebesar 25 berarti responden dominan menjawab dengan poin SS (sangat setuju), atau S (setuju) dan nilai rata-rata jawaban responden sebesar 20,18 pada pernyataan dalam kuesioner untuk variabel sikap etis. Nilai standar deviasi sebesar 2,80237 menunjukkan variasi jawaban responden tentang sikap etis terhadap nilai rata-ratanya sebesar 2,80237.

\section{Tabel 2. Statistik Deskriptif}

\begin{tabular}{llllll}
\hline & N & Minimum & Maximum & Mean & Std. Deviation \\
\hline SE & 150 & 12,00 & 25,00 & 20,1800 & 2,80237 \\
KE & 150 & 18,00 & 45,00 & 36,1933 & 3,51926 \\
KI & 150 & 22,00 & 44,00 & 33,6733 & 4,29686 \\
KS & 150 & 19,00 & 50,00 & 41,0333 & 4,30454 \\
\hline
\end{tabular}

Valid n (listwise) 150

Sumber: Data primer diolah 
Nilai minimum variabel kecerdasan emosional sebesar 18 yang berarti responden dominan menjawab dengan poin TS (tidak setuju) atau STS (sangat tidak setuju). Nilai maksimum sebesar 45 berarti responden dominan menjawab dengan poin SS (sangat setuju), atau S (setuju) dan nilai rata-rata jawaban responden sebesar 36,1933 pada pernyataan dalam kuesioner untuk variabel kecerdasan emosional. Nilai standar deviasi sebesar 3,51926 menunjukkan variasi jawaban responden tentang kecerdasan emosional terhadap nilai rata-ratanya sebesar 3,51926.

Nilai minimum variabel kecerdasan intelektual sebesar 22 yang berarti responden dominan menjawab dengan poin TS (tidak setuju) atau STS (sangat tidak setuju). Nilai maksimum sebesar 44 berarti responden dominan menjawab dengan poin SS (sangat setuju), atau S (setuju) dan nilai rata-rata jawaban responden sebesar 33,6733 pada pernyataan dalam kuesioner untuk variabel kecerdasan intelektual. Nilai standar deviasi sebesar 4,29686 menunjukkan variasi responden tentang kecerdasan intelektual terhadap nilai rata-ratanya sebesar 4,29686.

Nilai minimum variabel kecerdasan spiritual sebesar 19 yang berarti responden dominan menjawab dengan poin TS (tidak setuju) atau STS (sangat tidak setuju). Nilai maksimum sebesar 50 berarti responden dominan menjawab dengan poin SS (sangat setuju), atau S (setuju) dan nilai rata-rata jawaban responden sebesar 41,033 pada pernyataan dalam kuesioner untuk variabel kecerdasan spiritual. Nilai standar deviasi sebesar 4,30454 menunjukkan variasi jawaban responden tentang kecerdasan spiritual terhadap nilai rata-ratanya sebesar 4,30454.

\section{Hasil Uji Validitas Dan Uji Reliabilitas}

Berdasarkan hasil uji validitas diperoleh hasil bahwa semua butir pernyataan mempunyai koefisien lebih dari 0,159 sehingga semua instrumen dinyatakan valid. Sedangkan untuk uji reliabilitas, seluruh instrumen penelitian dinyatakan reliabel karena masing-masing butir pernyataan memiliki koefisien reliabilitas lebih besar dari nilai cronbach alpha 0,6. Hal ini menunjukkan bahwa pengukuran tersebut dapat memberikan hasil yang konsisten, apabila dilakukan pengukuran kembali terhadap subyek yang sama.

\section{Hasil Uji Asumsi Klasik}

Hasil uji normalitas menunjukkan koefisien Sig sebesar 0,2 yang lebih besar dari 0,05. Hal ini berarti data dalam penelitian ini berdistribusi normal. Dengan nilai tolerance dari masing-masing variabel lebih besar dari 10 persen atau 0,1 dan nilai VIF masing-masing variabel juga lebih kecil dari 10. Hal ini menunjukkan bahwa dalam regresi tidak terjadi gejala multikolinearitas. 
Berdasarkan hasil uji heterokedastisitas diketahui bahwa nilai Sig. masingmasing variabel independen berada diatas 0,05 sehingga dapat disimpulkan bahwa dalam model regresi yang digunakan tidak mengandung gejala heteroskedastisitas.

\section{Analisis Regresi Linier Berganda}

Untuk menjawab Hipotesis 1 sampai dengan 3 digunakan uji t yang diolah menggunakan SPSS. Hasil olah data yang dapat dilihat pada Tabel 6 menunjukkan bahwa secara parsial kecerdasan emosional dan kecerdasan spiritual tidak berpengaruh terhadap sikap etis, artinya $\mathrm{H}_{1}$ dan $\mathrm{H}_{3}$ ditolak. Sedangkan kecerdasan intelektual secara parsial berpengaruh signifikan terhadap sikap etis pada $\alpha$ sebesar 0,1 , sehingga $\mathrm{H}_{2}$ diterima.

Uji F digunakan untuk menjawab Hipotesis 4. Hasil olah data yang dapat dilihat pada Tabel 3 yang menunjukkan bahwa kecerdasan emosional, kecerdasan intelektual, dan kecerdasan spiritual secara simultan berpengaruh positif signifikan terhadap sikap etis mahasiswa akuntansi. Hal ini ditunjukan pada nilai signifikansi di bawah 0,1 , sehingga hipotesis yang menyatakan $\left(\mathrm{H}_{4}\right)$ diterima.

\section{Tabel 3. Hasil Uji Regresi Linier Berganda}

\begin{tabular}{lll}
\hline Hipotesis & Sig. & Keterangan \\
\hline $\mathrm{H}_{1}$ (Kecerdasan Emosional) & 0,381 & Reliabel \\
$\mathrm{H}_{2}$ (Kecerdasan Intelektual) & 0,095 & Reliabel \\
$\mathrm{H}_{3}$ (Kecerdasan Spiritual) & 0,438 & Reliabel \\
$\mathrm{H}_{4}$ (Kecerdasan Emosional, Intelektual, dan Spiritual) & 0,006 & Reliabel \\
\hline Sumber: Data primer diolah & &
\end{tabular}

\section{Pembahasan}

Dari serangkaian pengujian yang telah dilakukan, diperoleh hasil penelitian yang menyatakan bahwa kecerdasan emosional, kecerdasan intelektual, dan kecerdasan spiritual secara simultan berpengaruh positif signifikan terhadap sikap etis mahasiswa akuntansi. Hasil ini sejalan dengan penelitian dari Tikollah et al. (2006); Wardana \& Mimba (2016). Adanya pengaruh kecerdasan emosional, kecerdasan intelektual, dan kecerdasan spiritual terhadap sikap etis secara simultan sejalan dengan yang dinyatakan oleh Agoes \& Ardana (2009) bahwa kajian dan implementasi etika melibatkan kecerdasan emosional, kecerdasan intelektual dan kecerdasan spiritual secara terpadu.

Hasil penelitian ini secara parsial menunjukkan hanya kecerdasan intelektual berpengaruh positif signifikan terhadap sikap etis mahasiswa akuntansi. Hasil penelitian ini sejalan dengan penelitian dari Tikollah et al. (2006); Wardana \& Mimba (2016) yang membuktikan bahwa kecerdasan intelektual mempunyai pengaruh positif signifikan terhadap sikap etis. Kemudian dengan penelitian 
Tikollah et al. (2006) yang menyatakan bahwa mahasiswa sebagai anak didik dari suatu perguruan tinggi akan terdidik berdasarkan proses pendidikan yang berlangsung dalam lembaga pendidikan tersebut. Proses pendidikan yang berlangsung pada pendidikan akuntansi selama ini sangat menekankan pada aspek pencerdasan intelektualitas. Sementara pembentukan perilaku menyangkut dimensi emosi dan spiritual masih kurang diperhatikan.

Hasil penelitian ini menunjukkan bahwa secara parsial kecerdasan emosional dan kecerdasan spiritual tidak berpengaruh terhadap sikap etis mahasiswa akuntansi. Hal ini mendukung penelitian dari Fadli \& Djamhuri (2014); Tikollah et al. (2006). Hal ini diduga karena adanya pengaruh eksternal dari media yang menyoroti skandal etis yang dilakukan oleh para tokoh masyarakat maupun tokoh keagamaan. Pengaruh dari luar diri mahasiswa ini diduga dapat mempengaruhi sikap etis mahasiswa, karena tokoh yang dianggap dapat menjadi teladan untuk mahasiswa melakukan tindakan yang tidak etis. Selain itu, secara emosional mahasiswa belum terlibat langsung pada profesi akuntan, sehingga faktor kecerdasan emosional dan spiritual pada penelitian ini tidak berpengaruh terhadap sikap etis mahasiswa akuntansi.

\section{Simpulan}

Berdasarkan hasil analisis dan pembahasan hasil penelitian, dapat disimpulkan bahwa secara parsial kecerdasan intelektual berpengaruh positif signifikan terhadap sikap etis mahasiswa Progam Studi Akuntansi FEB UKSW, sedangkan kecerdasan emosional dan kecerdasan spiritual tidak berpengaruh pada sikap etis mahasiswa tersebut. Secara simultan kecerdasan emosional, kecerdasan intelektual, dan kecerdasan spiritual berpengaruh positif signifikan terhadap sikap etis mahasiswa Program Studi Akuntansi.

Implikasi pada penelitian ini adalah proses belajar-mengajar merupakan proses perkembangan manusia. Dalam proses perkembangan tersebut, ketiga aspek kecerdasan harus dikembangkan secara bersama-sama, sehingga menghasilkan mahasiswa yang memiliki sikap etis. Penelitian ini menjelaskan sebatas sikap etis terhadap profesi akuntan dalam kondisi responden belum pernah menjalaninya. Selain itu terdapat tingkat signifikansi yang lemah yaitu sepuluh persen.

Berdasarkan simpulan yang telah dijelaskan sebelumnya, dapat diberikan saran untuk penelitian selanjutnya dapat melakukan penelitian ini dengan responden yang telah menjadi akuntan profesional. Selain itu juga dapat menggunakan responden mahasiswa dan akuntan profesional untuk melihat perbedaan sikap etis terhadap profesi akuntan yang dipengaruhi oleh kecerdasan emosional, intelektual, dan spiritual. 


\section{Daftar Pustaka}

Agoes, S., \& Ardana, I. C. (2009). Etika Bisnis dan Profesi (Tantangan Membangun Manusia Seutuhnya). Jakarta: Salemba Empat.

Agustini, S., \& Herawati, N. T. (2013). Pengaruh Kecerdasan Intelektual, Kecerdasan Emosional dan Kecerdasan Spiritual Terhadap Sikap Etis Mahasiswa S1 Akuntansi Universitas Pendidikan Ganesha Singaraja. E-Journal Akuntansi Universitas Pendidikan Ganesha Singaraja, 1(1), 1-12. Retrieved from https://ejournal.undiksha.ac.id/index.php/S1ak/article/view/359/310

Boynton, W. C., Johnson, R. N., \& Kell, W. G. (2014). Modern Auditing (7th ed.). John Wiley \& Sons, Incorporated.

Dzulkifli, I. (2016). Fenomena (Baru) Dunia Pendidikan Etika. Retrieved January 18, 2019, from https://medium.com/@idzuldzulkifli/fenomena-baru-duniapendidikan-etika-f4712fdc11b5

Fadli, M., \& Djamhuri, A. (2014). Pengaruh Kecerdasan Emosional, Kecerdasan Spiritual, dan Kecerdasan Sosial Terhadap Sikap Etis Mahasiswa Akuntansi (Studi Pada Universitas Negeri Di Kota Malang). Jurnal Ilmiah Mahasiswa FEB Universitas Brawijaya.

Ghozali, I. (2013). Aplikasi Analisis Multivariate Dengan Program IBM dan SPSS. In aplikasi analisis multivariate dengan program ibm spss 19 (p. 113). https://doi.org/10.2307/1579941

Goleman, D. (2004). Kecerdasan Emosi untuk Mencapai Prestasi. Gramedia.

Hastuti, S. (2012). Perilaku Etis Mahasiswa dan Dosen Ditinjau dari Faktor Individual Gender dan Locus of Control (Studi Empiris Pada Fakultas Ekonomi Universitas X Di Jatim). Jurnal Riset Ekonomi \& Bisnis, 7(1), 58-73. https://doi.org/10.1234/JREBIS.V7I1.66

Ika, D. (2011). Pengaruh Kecerdasan Emosional dan Spiritual Terhadap Sikap Etis Mahasiswa Akuntansi Dipandang dari Segi Gender (Studi Pada Perguruan Tinggi Negeri Di Kota Medan). Jurnal Keuangan \& Bisnis, 3(2), 111-132.

Ikatan Akuntan Indonesia. (2016). Kode Etik Akuntan Profesional. Jakarta: Dewan Pengurus Nasional Ikatan Akuntan Indonesia.

Lawson, R. A. (2004). Is Classroom Cheating Related To Business Students' Propensity To Cheat In The "Real World"? Journal of Business Ethics, 49(2), 189-199. https://doi.org/10.1023/B:BUSI.0000015784.34148.cb

Malik, A. (2017). Mitra Ernst \& Young Indonesia Didenda Rp 13 Miliar di AS. Tempo.Co. Retrieved fromhttps://m.tempo.co/read/news/2017/02/11/087845604/mitra-ernstyoung-indonesia-didenda-rp-13-miliar-di-as

Maryani, T., \& Ludigdo, U. (2001). Survei atas Faktor-faktor yang Mempengaruhi Sikap dan Perilaku Etis Akuntan. Jurnal Telaah Ilmu Akuntansi, 2(1), 49-62.

Melandy, R., \& Aziza, N. (2006). Pengaruh Kecerdasan Emosional Terhadap Tingkat Pemahaman Akuntansi, Kepercayaan Diri Sebagai Variabel Pemoderasi. In Simposium Nasional Akuntansi 9 Padang (pp. 1-24).

Moustafa, K. S., \& Miller, T. R. (2003). Too Intelligent For The Job? The Validity Of UpperLimit Cognitive Ability Test Scores In Selection. SAM Advanced Management Journal,68(2).Retrievedfromhttp://www.freepatentsonline.com/article/SAM -Advanced-Management-Journal/103014927.html

Nursalam, Bani, S., \& Munirah. (2013). Bentuk Kecurangan Akademik (Academic Cheating) Mahasiswa PGMI Fakultas Tarbiyah Dan Keguruan UIN Alauddin Makassar. Lentera Pendidikan: Jurnal Ilmu Tarbiyah Dan Keguruan, 16(1), 127138. https://doi.org/10.24252/lp.2013v16n2a 
O'Clock, P., \& Okleshen, M. (1993). A Comparison Of Ethical Perceptions Of Business And Engineering Majors. Journal of Business Ethics, 12(9), 677-687. https://doi.org/10.1007/BF00881382

Patton, P. (2002). EQ-Kecerdasan Emosional Membangun Hubungan Jalan Menuju Kebahagiaan dan Kesejahteraan. Jakarta: Pustaka Delaprasata.

Purnamasari, D. (2013). Faktor-faktor yang Mempengaruhi Kecurangan Akademik Pada Mahasiswa. Educational Psychology Journal, 2(1), 13-21. Retrieved from file://D:/My Documents/Downloads/2581-Article Text-5082-1-1020131203.pdf

Purwanto, M. N. (2017). Psikologi Pendidikan. Bandung: Remaja Rosdakarya.

Rakhmat, J. (2005). Psikologi Komunikasi. (T. Surjaman, Ed.). BAndung: Remaja Rosdakarya.

Santoso, A. (2017). Direktur PT EKP Akui Suap Pejabat Ditjen Pajak Rp 6 M. Retrieved from https://news.detik.com/berita/d-3470165/direktur-pt-ekp-akui-suappejabat-ditjen-pajak-rp-6-m

Soetarno. (1994). Psikologi Sosial. Yogyakarta: Kanisius.

Suprayogi, A. (2017). Mantan Dirjen Dukcapil Kemendagri Divonis Kasus e-KTP. Retrieved from https://m.liputan6.com/amp/3028994/mantan-dirjendukcapil-kemendagri-divonis-kasus-e-ktp

Thurstone, L. L. (1928). Attitudes Can Be Measured. American Journal of Sociology, 33, 529554.Retrievedfromhttps://brocku.ca/MeadProject/Thurstone/Thurstone -1928a.html

Tikollah, R., Triyuwono, I., \& Ludigdo, U. (2006). Pengaruh Kecerdasan Intelektual, Kecerdasan Emosional dan Kecerdasan Spiritual Terhadap Sikap Etis Mahasiswa Akuntansi (Studi Pada Perguruan Tinggi Negeri Di Kota Makassar Provinsi Sulawesi Selatan). Simposium Nasional Akuntansi 9 Padang, 1-25.

Wardana, A., \& Mimba, N. (2016). Pengaruh Kecerdasan Intelektual, Kecerdasan Emosional, Kecerdasan Spiritual, dan Gender Pada Sikap Etis Mahasiswa Magister. E-Jurnal Ekonomi Dan Bisnis, 10, 3501-3530. Retrieved from http://ojs.unud.ac.id/index.php/EEB/article/view/22581

Zohar, D., \& Marshall, I. (2001). SQ: Memanfaatkan Kecerdasan Spiritual Dalam Berpikir Integralistik dan Holistik untuk Memaknai Kehidupan. Jakarta: Pustaka Mizan. 